\title{
Hubungan ANTARA SELF-CONFIDENCE TERHADAP MATEMATIKa DENGan KeMaMPUAN PEMECaHAN MASAlah SiSWA PADA Materi LINGKARAN
}

\author{
Senja Noviani Dewi ${ }^{1}$ dan Eva Dwi Minarti² \\ 1Program Studi Pendidikan Matematika IKIP Siliwangi \\ Jl. Terusan Jendral Sudirman, Baros, Kota Cimahi, Jawa Barat 40531, Indonesia \\ senja.airaaisha@gmail.com \\ ${ }^{2}$ Program Studi Pendidikan Matematika IKIP Siliwangi \\ Jl. Terusan Jendral Sudirman, Baros, Kota Cimahi, Jawa Barat 40531, Indonesia \\ kireina.arti@gmail.com
}

\begin{abstract}
Abstrak
Secara umum penelitian ini bertujuan untuk mengetahui terdapat atau tidaknya hubungan antara self-confidence siswa dan kemampuan pemecahan masalah siswa pada materi lingkaran. Metode yang digunakan dalam penelitian ini adalah metode survey dengan teknik korelasi. Populasi dalam penelitian ini adalah siswa SMP Negeri di Kota Bandung. Sedangkan sampel penelitiannya sebanyak 35 orang yang ditetapkan secara purposif pada salah satu SMP Negeri di Kota Bandung. Instrumen dalam penelitian ini berupa instrumen tes dan nontes, adapun instrumen tes sebanyak 6 soal untuk menganalisa kemampuan pemecahan masalah matematik siswa sedangkan instrumen nontes sebanyak 25 skala pernyataan yang digunakan untuk menganalisa self confidence siswa dalam pembelajaran matematik. Kesimpulan dari hasil penelitian ini adalah secara signifikan Self-confidence siswa pada pembelajaran matematika berpengaruh secara positif terhadap kemampuan pemecahan masalah matematik siswa.

Kata Kunci: Kemampuan Pemecahan Masalah, Self Confidence, Lingkaran.
\end{abstract}

\begin{abstract}
In general, the purpose of this research is to find out whether there is relationship between students' self-confidence and students' mathematic problem solving skill. The method of this research is survey method with corellation technique. The population of this research is students of a state junior high school in Bandung. While, the sample of this research is 35 students which is decided by purposif sampling in a state junior high school in Bandung. The instrument in this research is test and non-test instrument, in which test instrument consists of six questions to analyze students' mathematic problem solving skill, while non-test instrument consists of twenty five scale statement which is used to analyze students' self-confidence in mathematic learning. Conclusion of the result of this research is significantly, students'self-confidence in mathematic learning influence students' mathematic problem solving.

Keyword: Problem Solving Abilities, Self Confidence
\end{abstract}


http://journal.institutpendidikan.ac.id/index.php/mosharafa

\section{Pendahuluan}

Matematika merupakan bidang studi yang menduduki peranan penting dalam bidang pendidikan. Berbagai upaya perbaikan sistem pengajaran matematika dengan pendekatan atau dengan metode pembelajaran banyak dilakukan oleh tenaga pendidik. Perbaikan tersebut bertujuan untuk membentuk sumber daya manusia Indonesia yang memiliki pemikiran kritis, sistematis, logis, kreatif dan efektif sehingga dapat mengatasi berbagai tantangan dan permasalahan yang ada. Salah satu cara yang dapat dilakukan untuk mencapai tujuan tersebut adalah dengan mengembangkan program pendidikan yang berfokus pada pengembangan kemampuan berpikir.

Rata- rata skor prestasi anak-anak Indonesia dibandingkan negara-negara lain berada pada peringkat yang rendah. Informasi ini didasarkan pada hasil survei dari PISA (Coughlan, 2015) pada tahun 2015 Indonesia menduduki rangking 69 dari 76 negara. Fakta di lapangan menunjukkan kemampuan pemecahan masalah matematik masih cenderung rendah, hal ini dikarenakan siswa masih cenderung belum berhasil mengerjakan soal- soal pemecahan masalah yang diberikan. Selain itu juga siswa kurang dilatih untuk mengerjakan soal- soal non rutin, bagaimana menganalisa soal, mencari penyelesaian dari permasalahan matematik yang dihadapi (Tresnawati, Hidayat dan Rohaeti, 2017).

Kurangnya latihan mengerjakan soalsoal non rutin juga berakibat pada rendahnya kemampuan berpikir. Rendahnya kemampuan berpikir juga dapat berimplikasi pada rendahnya prestasi siswa. Menurut Wahyudin (1999: 223) di antara penyebab rendahnya pencapaian siswa dalam pelajaran matematika adalah proses pembelajaran yang belum optimal. Hal tersebut menyebabkan siswa kurang memiliki kemampuan fleksibilitas yang merupakan komponen utama kemampuan pemecahan masalah matematik. Fakta menunjukkan kurangnya perhatian terhadap kemampuan pemecahan masalah dalam matematika beserta implikasinya, dengan demikian adalah perlu untuk memberikan perhatian lebih pada kemampuan ini dalam pembelajaran matematika saat ini.

Lester, dan Kroll (dalam Ardiantari, 2015:8) menyatakan bahwa masalah adalah situasi dimana seseorang individu atau sekelompok orang menghadapi suatu tugas dimana tidak tersedia algoritma yang lengkap untuk menemukan solusinya. Pemecahan masalah merupakan hal yang begitu penting untuk belajar matematika. Dengan terbiasanya siswa dihadapkan dengan masalah yang dihadapi, maka siswa tersebut akan terbiasa menggunakan pola pikirnya sehingga dapat membantu keberhasilan orang tersebut dalam memecahkan kehidupan sehari-hari (Sundayana, 2016 : 79).

Pemecahan masalah merupakan hal yang sangat penting dalam pembelajaran matematika. Pentingnya pemilikan kemampuan Pemecahan masalah menurut 
Branca (Sumarmo dan Hendriana, 2014:445), "Pemecahan masalah matematik merupakan salah satu tujuan penting dalam pembelajaran matematika bahkan proses pembelajaran matematik merupakan jantungnya matematika“. Selain itu Cooney (Sumarmo dan Hendriana, 2014:445) mengemukakan bahwa pemilikan kemampuan pemecahan masalah membantu siswa berpikir analitik untuk mengambil keputusan dalam kehidupan sehari- hari dan membantu meningkatkan kemampuan berpikir kritis dalam menghadapi situasi yang baru.

Menyadari pentingnya matematika dalam memecahkan masalah sehari- hari, sehingga siswa berani mengungkapkan ide - ide yang dimilikinya untuk mendapatkan kemungkinan penyelesaian sehingga diperlukan pendekatan pembelajaran yang tepat untuk meningkatkan kemampuan siswa dalam memecahkan masalah. Selain itu Ausubel (dalam Ruseffendi, 2006:291) menyarankan sebaiknya dalam pembelajaran digunakan pendekatan yang menggunakan metode pemecahan masalah, inquiri, dan metode belajar yang dapat menumbuhkan berpikir kreatif dan kritis.

Perlu diupayakan pembelajaran matematika yang dapat meningkatkan kemampuan pemecahan masalah siswa. Agar kemampuan tersebut dapat berkembang dengan baik, maka dalam proses pembelajaran matematika, guru perlu memberikan kesempatan kepada siswa untuk dapat meningkatkan kemampuan mereka dalam mengembangkan ide- ide matematisnya. Untuk mengembangkan ide- ide siswa, guru diharapkan menyusun strategi pembelajaran dengan memanfaatkan berbagai media dan sumber belajar. Untuk mendorong terciptanya kemudahankemudahan dalam mengakses informasi dan memperkecil waktu yang diperlukan untuk memperoleh pengetahuan tersebut, sehingga proses yang dibutuhkan untuk mencapai pemecahan masalah terhadap suatu pelajaran dapat lebih cepat.

Selain kemampuan pemecahan masalah, terdapat aspek psikologi yang turut memberikan kontribusi terhadap keberhasilan seseorang dalam menyelesaikan tugas dengan baik. Rendahnya kemampuan pemecahan masalah matematis siswa ternyata menimbulkan dampak pada sikap yang harusnya dimiliki siswa yaitu sikap percaya diri (self confidence). Hal ini berdasar pada penelitian yang dilakukan Arslan dan Altun (Minarti, 2015:170) di Turki, bahwa minimnya pengetahuan dan keterampilan peserta didik, seperti konsep, algoritma, dan pemecahan masalah, mengakibatkan ketidakpercayaan diri pada siswa dalam menghadapi masalah matematis. Kloosterman (Minarti, 2015:170) mengemukakan bahwa keberhasilan dan kegagalan yang dicapai siswa kelas tujuh dipengaruhi oleh motivasi, kepercayaan diri dan keyakinan akan usaha yang mereka lakukan dalam pembelajaran matematika.

Secara sederhana self confidence atau percaya diri berarti rasa percaya terhadap 
kemampuan diri mencapai prestasi yang menjadi indikator Self Confidence tertentu. Menurut penelitian yang dilakukan Suhardita (2010), siswa akan memperoleh rasa percaya diri dari pengalaman hidup dan berhubungan dengan kemampuan melakukan sesuatu dengan baik. Dengan demikian dengan rasa percaya diri siswa akan dapat mengaktualisasikan potensi yang ada pada dirinya.

Yates (dalam Hendriana, Rohaeti, dan Sumarmo, 2017:198) menjelaskan bahwa kepercayaan diri sangat penting bagi siswa agar berhasil dalam belajar matematika. Dengan adanya rasa percaya diri, maka siswa akan lebih termotivasi dan lebih menyukai untuk belajar matematika sehingga pada akhirnya diharapkan prestasi belajar matematika yang dicapai juga lebih optimal.

Secara umum penelitian ini bertujuan untuk mengetahui terdapat atau tidaknya hubungan antara self-confidence siswa dan kemampuan pemecahan masalah matematik siswa. Kemampuan pemecahan masalah matematik dalam penelitian ini adalah kemampuan siswa yang meliputi kemampuan, a) memahami masalah meliputi mengidentifikasi data yang diketahui, mengidentifikasi data yang ditanyakan, mengidentifikasi data yang diperlukan, memeriksa kecukupan data, dan menyusun model matematika, b) Memilih strategi dan melaksanakan strategi, c) Melaksanakan perhitungan atau menyelesaikan model matematik, d) Menginterpretasi solusi ( hasil) ke masalah awal memeriksa kebenaran solusi. Adapun dalam penelitian ini adalah a) Percaya kepada kemampuan diri sendiri, b) Bertindak mandiri dalam mengambil keputusan, c) Memiliki konsep diri yang positif, d) Berani memgungkapkan pendapat.

\section{Metode}

Metode yang digunakan dalam penelitian ini adalah metode survey dengan teknik korelasi yaitu mencari hubungan antara self-confidence dengan kemampuan pemecahan masalah matematik siswa. Populasi dalam penelitian ini adalah siswa SMP Negeri di Kota Bandung. Sedangkan sampel penelitiannya sebanyak 35 orang yang ditetapkan secara purposif pada salah satu SMP Negeri di Kota Bandung. Instrumen dalam penelitian ni berupa instrumen tes dan nontes, adapun instrumen tes sebanyak 6 soal untuk menganalisa kemampuan pemecahan masalah siswa sedangkan instrumen nontes sebanyak 25 skala pernyataan yang digunakan untuk menganalisa self confidence siswa dalam pembelajaran matematik.

Tes Matematika yang digunakan berupa tes kemampuan pemecahan masalah. Agar kemampuan pemecahan masalah matematik siswa dapat terlihat dengan jelas maka tes dibuat dalam bentuk uraian. Untuk memperoleh soal tes yang baik maka soal tes tersebut harus dinilai validitas, reliabilitas, tingkat kesukaran dan daya pembeda. Untuk mendapatkan validitas, reliabilitas, tingkat kesukaran dan 
daya pembeda maka soal tersebut terlebih dahulu diuji cobakan pada kelas lain di sekolah pada tingkat yang sama. untuk menghitung validitas butir soal reliabilitas, tingkat kesukaran, dan daya pembeda menggunakan program Microsof Excel.

Pengembangan instrumen variabel self confidence siswa tentang matematika diawali dengan penyusunan 25 butir pernyataan yang dilengkapi dengan 4 pilihan jawaban yaitu SS (Sangat Setuju), S (Setuju), TS (Tidak Setuju), STS (Sangat Tidak Setuju), Setiap pilihan jawaban yang diajukan memiliki skor antara 1 sampai 4 . Skor variabel dapat diperoleh dengan cara menjumlahkan seluruh skor butir. Proses kalibrasi instrumen dilaksanakan dengan melakukan ujicoba kepada 35 responden. Pada tahap ujicoba instrumen dilakukan pengujian validitas butir soal dan perhitungan koefisien reliabilitas.

Data self confidence yang awalnya merupakan data ordinal di konversi menjadi data interval, penentuan skor berdasarkan sebaran jawaban siswa yang pada akhirnya menghasilkan data dalam skala interval, proses ini dinamakan transformasi data. Transformasi data ini, dilakukan diantaranya adalah dengan menggunakan Metode Sucsesive Interval. Pada umumnya jawaban responden yang diukur dengan menggunakan skala likert (Lykert scale) diadakan scoring yakni pemberian nilai numerikal 1, 2, 3, dan 4, setiap skor yang diperoleh akan memiliki tingkat pengukuran ordinal. Nilai numerikal tersebut dianggap sebagai objek dan selanjutnya melalui proses transformasi ditempatkan ke dalam interval. Data hasil penelitian diolah dan dianalisis menggunakan uji statistik.

Adapun contoh instrumen tes dan nontes yang diberikan disajikan di bawah ini (gambar 1 dan 2). 
1. Sebuah taman berbentuk seperti gambar di bawah dengan kolam ikan ditengahnya , jika luas seluruh taman tersebut $240 \mathrm{~m}^{2}$, Bagaimana langkahlangkah untuk menentukan luas kolam ikan tersebut? Tunjukkan luas kolam ikan yang kamu peroleh benar !

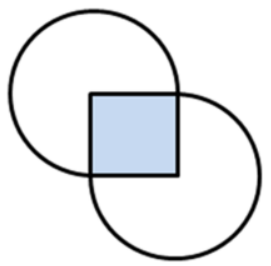

2.Pak Agus akan membuat taman berbentuk lingkaran, Di tengah- tengah taman tersebut akan dibuat kolam berbentuk lingkaran. Sketsa taman tersebut dibuat terlebih dahulu dengan skala 1:700. Pada sketsa, taman tersebut berdiameter 3 $\mathrm{cm}$ dan diameter kolam $2 \mathrm{~cm}$. Jika tanah di sekeliling kolam akan ditanami rumput dengan biaya Rp. $12.000,00$ per $\mathrm{m} 2$,

a. Gambarlah sketsa situasi tersebut !

b. Bagaimana langkah- langkah untuk menentukan biaya menanam rumput pada taman tersebut? Bagaimanakah kamu menunjukkan jawabanmu benar?

Gambar 1. Instrumen Tes Tentang Kemampuan Pemecahan Masalah Matematik Siswa

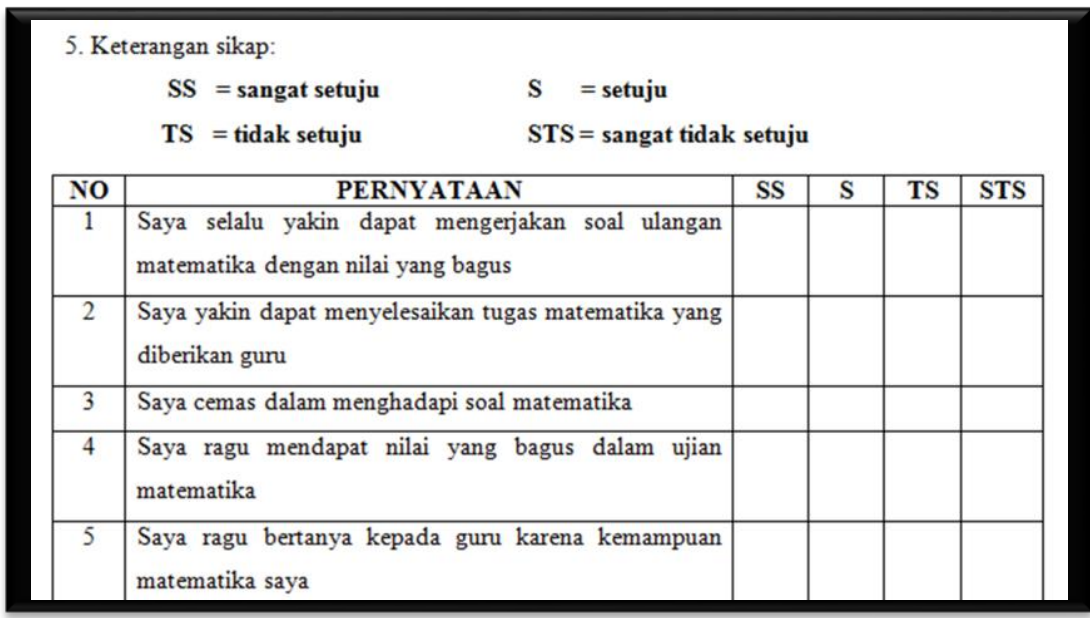

Gambar 2. Instrumen Non Tes Tentang Self Confidence Siswa

\section{Hasil dan Pembahasan}

Pada dasarnya kemampuan pemecahan masalah matematik merupakan satu kemampuan matematis yang penting dan perlu dikuasai oleh siswa yang belajar matematika. Rasional yang mendasari kebenaran pernyataan tersebut diantaranya adalah : a) Branca (dalam Sumarmo, 2006) mengemukakan bahwa pemecahan masalah matematis meliputi metode, prosedur dan strategi yang merupakan proses inti dan utama dalam kurikulum matematika atau merupakan tujuan umum pembelajaran matematika, bahkan sebagai jantungnya matematika. Selain itu pemecahan masalah merupakan satu 
kemampuan dasar dalam pembelajaran matematika;

b) Pemecahan masalah matematis membantu individu berpikir analitik;

c) Belajar pemecahan masalah matematis pada hakikatnya adalah belajar berpikir, bernalar, dan menerapkan pengetahuan yang telah dimiliki.

Pemecahan masalah matematis membantu berpikir kritis, kreatif dan mengembangkan kemampuan matematis lainnya. Polya (dalam Ardiantari, 2015:8) mengemukakan bahwa pemecahan masalah adalah suatu usaha mencari jalan keluar dari suatu tujuan yang tidak begitu mudah segera dapat dicapai. Untuk melihat seberapa kuat hubungan antara self-confidence dan kemampuan pemecahan masalah matematik, maka dilakukan uji korelasi Pearson dengan $\alpha=$ 0,05 .

Tabel 1.

Hasil Uji Korelasi self-confidence dan Kemampuan

Pemecahan Masalah Matematik

\begin{tabular}{|ll|r|r|}
\hline & & $\begin{array}{c}\text { Pemecahan_ } \\
\text { Masalah }\end{array}$ & $\begin{array}{c}\text { Self__conce } \\
\text { Confidence }\end{array}$ \\
\hline Pemecahan_Masalah & Pearson Correlation & 1 & $.947^{\times \pi}$ \\
& Sig. (2-tailed) & & .000 \\
& $\mathrm{~N}$ & 35 & 35 \\
\hline Self_Confidence & Pearson Correlation & $.947^{\times \pi}$ & 1 \\
& Sig. (2-tailed) & .000 & 35 \\
& $\mathrm{~N}$ & 35 & \\
&
\end{tabular}

*. Correlation is significant at the 0.01 level (2-tailed).

Dari Tabel 1, diperoleh hasil korelasi antara self-confidence dan kemampuan pemecahan masalah matematik siswa adalah 0,947 dan nilai signifikansi (sig) sebesar 0,000. Harga korelasi $(r)$ yang diperoleh adalah 0,947 yang artinya tingkat hubungannya tergolong kuat. Karena nilai signifikansi 0,000 lebih kecil dari $\alpha=0,05$ maka terdapat hubungan yang signifikan antara self-confidence dan kemampuan pemecahan masalah matematik siswa. Hal ini sesuai dengan yang dikemukakan oleh Lauster (dalam Hendriana, Rohaeti, dan Sumarmo, 2017:197) bahwa kepercayaan diri merupakan suatu sikap atau perasaan yakin akan kemampuan diri sendiri sehingga orang yang bersangkutan tidak terlalu cemas dalam tindakantindakannya, dapat merasa bebas untuk melakukan hal- hal yang disukainya, dan bertanggung jawab atas tindakannya, memiliki dorongan untuk berprestasi serta mengenal kelebihan dan kekurangan dirinya. Percaya terhadap kemampuan diri ini akan mempengaruhi tingkat prestasi atau kinerja yang bersangkutan.

Hal serupa juga dikemukakan Yates (dalam Hendriana, Rohaeti, dan Sumarmo, 2017:198) menjelaskan bahwa kepercayaan diri sangat penting bagi siswa agar berhasil dalam belajar matematika. 
Dengan adanya rasa percaya diri, maka kemampuan pemecahan masalah siswa akan lebih termotivasi dan lebih matematik maka dilakukan pengujian menyukai untuk belajar matematika koefisien regresi dengan menggunakan sehingga pada akhirnya diharapkan analisis regresi linier. Analisis ini dilakukan prestasi belajar matematika yang dicapai juga lebih optimal.

Untuk mengetahui bagaimana hubungan antara self-confidence dengan untuk melihat pengaruh langsung dari selfconfidence siswa terhadap kemampuan pemecahan masalah matematik siswa.

Hasil analisis dapat dilihat pada Tabel 2.

Tabel 2.

Hasil Analisis Regresi Self-Confidence dengan

Kemampuan Pemecahan Masalah Matematik

\begin{tabular}{|c|c|c|c|c|c|c|}
\hline \multirow{2}{*}{\multicolumn{2}{|c|}{ Madel }} & \multicolumn{2}{|c|}{ Unstandardized Coefficients } & \multirow{2}{*}{$\begin{array}{c}\begin{array}{c}\text { Standardized } \\
\text { Coefficients }\end{array} \\
\text { Beta } \\
\end{array}$} & \multirow[b]{2}{*}{$t$} & \multirow[b]{2}{*}{ Sig. } \\
\hline & & $\mathrm{B}$ & Std. Error & & & \\
\hline \multirow[t]{2}{*}{1} & (Constant) & -66.684 & 6.120 & & -10.897 & .000 \\
\hline & Self_Confidence & 1.687 & .100 & .947 & 16.948 & .000 \\
\hline
\end{tabular}

a. Dependent Variable: Pemecahan_Masalah

Dari tabel 2 di atas dapat diketahui persamaan regresinya adalah $Y=-66,684+$ $1,687 x$ yang artinya, semakin besar nilai self-confidence siswa maka semakin besar kemampuan pemecahan masalah matematik siswa, begitu juga sebaliknya.

Karena nilai signifikansi 0,000 $<0,05$ maka dapat disimpulkan bahwa secara signifikan Self-confidence siswa tentang matematika dalam pembelajaran mempengaruhi kemampuan pemecahan masalah matematik siswa. Sehingga siswa yang memiliki kemampuan pemecahan masalah matematik yang baik, juga memiliki self-confidence yang baik.

Mengenai kaitan antara self-confidence dengan kemampuan pemecahan masalah, semakin seseorang percaya diri dalam belajarnya, maka kemampuan pemecahan masalah matematisnya akan meningkat. Hasil penelitian ini sesuai dengan penelitian Fitriani (2015: 10) yang menyatakan bahwa dalam pembelajaran matematika yang menggunkan pendekatan PMR akan meningkatkan kemampuan pemecahan masalah matematis siswa, dan juga berdampak langsung pada peningkatan self confidence yang dimiliki oleh siswa.

\section{Penutup}

Berdasarkan hasil analisi data mengenai hubungan antara self-confidence siswa dan kemampuan pemecahan masalah matematik pada materi lingkaran, kesimpulan dari hasil temuan yang diperoleh adalah self-confidence siswa dalam pembelajaran matematik secara signifikan mempengaruhi kemampuan pemecahan masalah matematik siswa.

Self-confidence yang ditelaah pada penelitian ini merupakan Self-confidence 
yang terkait dengan kemampuan pemecahan masalah matematik. Peneliti selanjutnya dapat meneliti Self-confidence siswa yang terkait dengan kemampuan matematik lainnya.

\section{Daftar Pustaka}

Ardiantari, N. L. P. (2015). Penerapan Pendekatan Saintifik dengan Penilaian Proyek untuk Meningkatkan Kemampuan Pemecahan Masalah dan Hasil Belajar Pengetahuan Matematika Tema Cita- Citaku Siswa Kelas IV B SD Negeri 8 Pemecutan. Jurnal Undiksa Vol.3.no.1, 8.

Coughlan S. (2015). Asia Peringkat Tertinggi Sekolah Global Indonesia Nomor 69. Koresponden Pendidikan BBC. Diakses tanggal 24 Februari 2018 dari

www.bbc.com/indonesia/majalah/201 5/05/150513_majalah_asia_sekolah_t erbaik.

Fitriani, N. (2015). Hubungan antara Kemampuan Pemecahan Masalah Matematis dengan Self Confidence Siswa SMP yang Menggunakan Pendekatan Pendidikan Matematika Realistik. Jurnal Euclid, vol.2, No.2.

Hendriana, H. dan Sumarmo, U. (2014). Penilaian Pembelajaran Matematika. Bandung: Refika Aditama.

Hendriana, H., Rohaeti, E. E.,Sumarmo, U. (2017). Hard Skills dan Soft Skills Matematik Siswa. Bandung: Refika Aditama.

Minarti, E. D. dan Senjayawati, E. (2015). Studi Komperatif Penerapan Pendekatan Kontekstual dan Pendekatan Kontekstual Bersetting
Pembelajaran Cooperatif Script Terhadap Kemampuan Representasi Matematis dan Self Confidence Siswa SMK di Kota Cimahi. Jurnal IImiah UPT P2M STKIP Siliwangi vol.2.no.2.

Ruseffendi, E.T. (2006). Pengantar kepada Membantu Guru Mengembangkan Kompetensinya dalam Pengajaran Matematika untuk Meningkatkan CBSA. Bandung: Tarsito.

Suhardita, K. (2010). Efektivitas Penggunaan Teknik Permainan dalam Bimbingan Kelompok untuk Meningkatkan Percaya Diri Siswa. Skripsi UPI tidak diterbitkan.

Sumarmo, U. (2006). Pembelajaran Keterampilan Membaca Matematika pada Siswa Sekolah Menengah. Prosiding Seminar Nasional Matematika UPI Bandung.

Sundayana, R. (2016). Kaitan antara Gaya Belajar, Kemandirian Belajar, dan Kemampuan Pemecahan Masalah Siswa SMP dalam Pelajaran Matematika. Mosharafa: Jurnal Pendidikan Matematika, Volume 5, Nomor 2.

Tresnawati., Hidayat, W., Rohaeti, E. E. (2017). Kemampuan Berpikir Kritis Matematis dan Kepercayaan Diri Siswa SMA. Pasundan Journal of Research in Mathematics Learning and Education vol.2.no.2.

Wahyudin. (1999). Kemampuan Guru Matematika, Calon Guru Matematik, dan Siswa Dalam Mata Pelajaran Matematika. Bandung: Disertasi PPS IKIP Bandung: Tidak diterbitkan. 
This page is intentionally left blank 